ELORE (ISSN 1456-3010), vol. $17-1 / 2010$.

Julkaisija: Suomen Kansantietouden Tutkijain Seura ry. [http://www.elore.fi/arkisto/1_10/ajankoht_moberg_1_10.pdf]

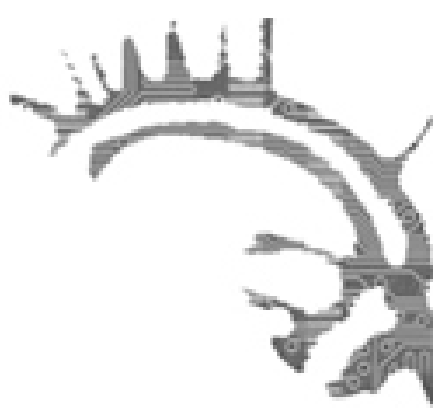

AKTUELLT

\title{
Kristen metallmusik. Alternativt religiöst UTTRYCKSSÄTT OCH KRISTEN IDENTITET
}

Lectio precursoria i Abo Akademi 4.12.2009

\section{Marcus Moberg}

Dagens västerländska samhällen präglas av kulturell och religiös mångfald. Forskningen i religiös förändring i västvärlden har länge koncentrerat sig på hur denna pluralistiska situation medfört en mängd utmaningar för de traditionella och institutionella kristna kyrkorna. Dessa har sedan en längre tid tillbaka börjat ställas inför frågan ifall de förlorat sitt tolkningsföreträde på svaren till de stora livsfrågorna och istället blivit ett alternativ bland många.

Inom senare religionssociologiska strömningar har man dock alltmer fäst uppmärksamhet vid hur ett minskat intresse för traditionell kristendom i många avseenden har gått hand $i$ hand med ett ökat intresse för individcentrerade och upplevelsebetonande alternativa religioner och andlighetsformer. Denna fråga har under en längre tid dominerat den religionssociologiska debatten på en internationell nivå.

Denna utveckling har även berört Finland på en mängd olika sätt. Forskningen i de förändringar som finländares religiösa liv genomgått sedan en längre tid tillbaka har särskilt framhållit att det religiösa livet blivit allt mer privatiserat. Det traditionella sekulariseringsparadigmet har visat sig utgöra en bristfällig förklaringsmodell för de förändringar som det religiösa fältet genomgått $i$ en senmodern västerländsk kontext. Religionssociologin står $i$ dagens läge inför utmaningen att förklara vad som kommit att kallas det post-sekulära samhället och kulturen.

Detta kräver att mer nyanserade perspektiv på religiös förändring bör anlitas som särskilt uppmärksammar de sätt på vilka det religiösa livet håller på att ändra form och som också ser till hur livet inom de traditionella kristna kyrkorna påverkats av och anpassat sig till dagens religiösa och kulturella klimat. Jag placerar mig också i denna tolkningstradition och kommer i det följande att föra fram några centrala aspekter av 
detta samt hur min egen studie bidrar till denna debatt, särskilt i en finländsk kontext. Jag skall börja med att diskutera hur allt fler forskare framhållit den centrala roll som populärkulturen kommit att spela inom dagens föränderliga religiösa landskap. Jag skall sedan i korthet redogöra för det kristna populärkulturella fenomen som utgör ämnet för min avhandling samt det huvudsakliga teoretiska och metodologiska närmandesätt som min forskning baserar sig på. Slutligen skall jag sedan diskutera hur min forskning bidrar till den aktuella debatten om religiös förändring i Finland.

Som nämndes ovan har det västerländska religiösa klimatet sedan en längre tid tillbaka genomgått en mängd genomgripande förändringar. Av speciell betydelse för min egen forskning har det härvid varit att betona det som också en växande mängd övriga forskare börjat argumentera för under senare år, nämligen den allt mer centrala roll som populärkulturen kommit att spela inom denna utveckling. Populärkulturen har i dagens läge kommit att utgöra en allt mer central inspirationskälla för allt fler människors konstruktion av den egna religiösa identiteten. Därtill har populärkulturen även starkt påverkat de former och sätt på vilka allt fler människor utövar och praktiserar sin religion inom ramen för sina vardagliga liv. Detta har under senare år särskilt uppmärksammats av forskare som Gordon Lynch, Stewart M. Hoover, Lynn Clark och Christopher Partridge.

Min egen forskning faller inom det delområde inom detta bredare forskningsfält som särskilt koncentrerar sig på hur den här utvecklingen på inget sätt lämnat livet inom de traditionella kristna kyrkorna opåverkat. Populärkulturen har sedan en längre tid tillbaka allt mer börjat göra sig till känna även inom kristna sammanhang. Historiskt sett har det givetvis alltid förekommit en nära växelverkan mellan de kristna kyrkorna och den omliggande samtida kulturen. På ett internationellt plan kan vi dock i dagens läge finna ett flertal exempel på kristna grupper som medvetet och uttryckligen börjat ersätta traditionella religiösa uttryckssätt med särskilda populärkulturella former, oftast olika former av populärmusik.

Inom forskningen i dagens förhållande mellan kristendom och populärkultur har man framför allt koncentrerat sig på vad som, efter engelskans evangelical, kommit att kallas evangelikal protestantism eller evangelikalism. Evangelikalismen skall dock inte förstås som utgörande ett kristet samfund i sig utan i första hand betraktas som en viss typ av protestantisk väckelsefromhet och trosinriktning. Till den moderna evangelikalismens främsta kännetecken hör betonandet av det personliga och individuella engagemanget med den egna tron samt framhållandet av subjektiva religiösa upplevelser. Den kännetecknas därtill å ena sidan av den stora vikt den fäster vid lekmanna-engagemang och, å andra sidan, av den mindre vikt den fäster vid doktrinella detaljer och specifika samfundsläror. På detta sätt återspeglas även dagens bredare allt mer individcentrerade och upplevelsebetonade religiösa klimat även inom den evangelikala kristna kontexten. Det är även viktigt att notera att evangelikalismen spridit sig på ett internationellt plan. Dess inflytande påträffas i dagens läge inom en mängd olika protestantiska kristna samfund.

Denna typ av observationer kan i dagens läge även göras inom ramen för den samtida finländska kontexten. Evangelikalismen har utan tvekan även fått ett allt mer synligt fotfäste inom såväl många frikyrkliga som väckelseinriktade lutherska kretsar 
i Finland. Evangelikalismen har därtill länge betraktats som ett primärexempel på hur också kristna grupper sedan en längre tid tillbaka allt mer påverkats av och anpassat sig till dagens konsumtionscentrerade populärkulturella klimat. Detta belyses framför allt genom uppkomsten av en internationell så kallad evangelikal eller kristen populärmusikindustri.

Den kristna populärmusiken, vanligen sammanfattad under begreppet Contemporary Christian Music, uppstod i USA i slutet av 1960-talet som ett kristet alternativ till den sekulära eller världsliga populärmusiken och de värderingar den ansågs representera. Den kristna populärmusiken kännetecknas särskilt för den samling krav den ställer på sångtexter, artister och organisation. Till dessa hör framför allt att sångtexterna inom den kristna populärmusiken bör behandla klart kristna teman, att musiken bör skapas och framföras av uttalat kristna artister, samt att den bör produceras och distribueras av kristna bolag med en mer eller mindre uttalad religiös agenda.

Den kristna populärmusiken har spelat en viktig roll i hur traditionella religiösa uttrycksformer alltmer kommit att ersättas med kulturellt relevanta alternativ inom en mängd kristna kretsar världen över. För allt fler unga kristna idag har den kristna populärmusiken även kommit att erbjuda ett annorlunda och alternativt sätt att uttrycka och utöva den kristna tron på. I vissa fall har direkta kombinationer mellan kristendom och olika populärmusikformer uppstått. Denna utveckling har också noterats inom forskningen i religiös förändring i Finland, men mer omfattande och detaljerade empiriska studier saknas tills vidare. Avsaknaden av empiriska studier beror dock huvudsakligen på att kristna grupper som medvetet och uttryckligen sammankopplat sitt religiösa liv med någon särskild populärkulturform tills vidare utgjort ett sällsynt fenomen i vårt land. Min avhandling fokuserar på ett sådant fall: den kristna metallmusikscenen.

Många personer känner i dagens läge till metallmusiken som en av Finlands mest populära musikformer och som en av vårt lands främsta populärkulturella exportvaror. De flesta känner dock även till metallmusiken som en av vår tids mest extrema, kontroversiella och omdiskuterade populärmusikformer. Det är därtill allmänt välkänt att metallmusiken ända sedan sin uppkomst i slutet av 1960-talet anklagats för uppmuntrande till extrem revolt, våld och självdestruktivt beteende - som självmord, drog- och alkoholmissbruk - samt, sist men inte minst, satanism och regelrätt djävulsdyrkan. Denna kritik har framför allt framförts från konservativt kristet håll. Själva förekomsten av något sådant som kristen metallmusik kan därför förefalla märkligt. Så vad är kristen metallmusik?

Kristen metallmusik uppstod som en del av den kristna populärmusiken i USA i slutet av 1970-talet då en mindre grupp evangelikala kristna musiker upptog metallmusiken i det uttryckliga syftet att sprida det kristna budskapet i den sekulära metallmusikkulturen. Grundtanken var att bemöta sekulära metallmusikanhängare på ett sådant sätt och med ett sådant språk som de skulle kunna förstå. Vid sidan av musiken upptog man dock redan från början även sin sekulära motsvarighets kompromisslösa attityd, dess radikala retorik, stil, estetik och i viss bemärkelse även livsstil. Den sekulära metallmusikens individualistiska och anti-auktoritära ideologi ersattes dock med ett uttryckligt framhållande av den kristna läran, kristen moral och kristna 
värderingar. På grund av den sekulära metallmusikens radikala och extrema karaktär mottogs den kristna metallmusiken dock inte lika väl inom alla kristna samfund. Även om missionstanken förblivit central utvecklades den kristna metallmusiken med tiden även till en självständig kristen musikkultur. I början av 1990-talet hade den spridit sig till en mängd olika länder utanför USA, däribland Finland. I Finland förekommer i dagens läge en växande och livskraftig kristen metallmusikscen med ca 500 aktiva kärnmedlemmar.

I samband med att den kristna metallmusiken spridit sig till en mängd olika länder har den även utvecklat en egen och långtgående Internetbaserad självständig transnationell infrastruktur bestående av sina egna skivbolag, egna distributions- och promotionskanaler, sina egna specialiserade medier, samt sina egna festivaler. Denna utveckling har möjliggjort uppkomsten av vad som $i$ avhandlingen kallas en transnationell kristen metallmusikscen. Avhandlingen bidrar med en detaljerad redogörelse för den kristna metallmusikscenens historiska utveckling och nutida struktur på såväl ett transnationellt som finländskt nationellt plan. Jag uppmärksammar härvid särskilt den kontakt, det samarbete och den växelverkan mellan kristna metallmusikscener i olika länder som utvecklingen av en transnationell infrastruktur möjliggjort.

Denna redogörelse utgör bakgrunden mot vilken studien sedan fortskrider med en undersökning av vilken huvudsaklig mening och funktion som musiken tillskrivs diskursivt bland de egna anhängarna på ett transnationellt plan. I denna diskursiva konstruktion presenteras den kristna metallmusiken huvudsakligen som utgörande ett fullt legitimt alternativt religiöst uttryckssätt och missionsredskap. Den framställs därmed som ett medvetet och uttryckligen annorlunda, kraftfullt och upplevelsebetonande sätt att uttrycka, utöva och sprida den kristna tron på.

I ljuset av denna diskursiva konstruktion på ett transnationellt plan fortsätter studien sedan med en undersökning av vilken huvudsaklig mening och funktion som finländska kristna metallmusiker tillskriver musiken och sitt eget aktiva medverkande $i$ dagens finländska scen. Finländska kristna metallmusikers redogörelser för sin uppfattning av musikens grundläggande mening och funktion uppvisar klara samband med hur denna grundläggande mening och funktion konstrueras diskursivt på ett transnationellt plan. Finländska kristna metallmusiker beskriver därtill den finländska nationella scenen i sig som utgörande en på samma gång musikalisk och religiös gemenskap inom vilken olika samfundstillhörighet blir av sekundär betydelse.

I en finländsk kontext har detta möte mellan kristendom och metallmusik sålunda resulterat i ett distinkt, samtidigt både religiöst och kulturellt rum som existerar i gränslandet mellan traditionell religion och populärkultur. Jag argumenterar därför för att den kristna metallmusiken på detta sätt utgör ett synnerligen gott nutida exempel på en medveten och direkt kombination av kristendom och populärkultur som erbjuder sina anhängare en mängd resurser för skapandet av en egen och säregen alternativ kristen identitet. Detta är i korthet den tolkning av fenomenet kristen metallmusik som jag presenterar i min avhandling. I det följande skall jag kort redogöra för det socialkonstruktionistiska perspektiv som utgör grunden för denna tolkning.

Ett socialkonstruktionistiskt perspektiv uppmärksammar särskilt de sätt på vilka människors skapande av en meningsfull verklighet alltid sker i relationella och kom- 
munikativa kontexter, särskilt genom vår språkanvändning. För den enskilde forskaren inbegriper detta framför allt en ständig strävan efter självreflexiv medvetenhet om hur den egna forskningsdisciplinen, de egna särskilda forskningsintressena, den egna personliga bakgrunden, de egna förförståelserna och de egna fördomarna, på olika sätt påverkar forskningsprocessens alla skeden. Den bild och tolkning av den finländska kristna metallmusikscenen som jag presenterar i min studie bör sålunda betraktas som resultatet av ett samarbete mellan mig och mina informanter inom den kristna metallmusikscenen i Finland.

I enlighet med mitt socialkonstruktionistiska närmandesätt strävar jag i avhandlingen sålunda efter att skapa en konstruktiv dialog mellan de teoretiska perspektiv som jag anlitar och det etnografiska primärmaterial som jag själv samlat in och som utgör grunden för min studie. Å ena sidan inbegriper detta en strävan att bidra med en så nyanserad tolkning av primärmaterialet som möjligt. $\AA$ andra sidan inbegriper det också en strävan att utveckla och förfina de teoretiska perspektiv som jag anlitar.

I detta sammanhang bör vi även slutligen ställa oss frågan vad den kristna metallmusikscenen säger mer allmänt om unga kristnas syn på kristet liv i dagens Finland. För det första bör det noteras att den kristna metallmusikscenen utgör ett för finländska förhållanden tills vidare mycket sällsynt exempel på en grupp unga kristna som medvetet och uttryckligen direkt kombinerat sitt religiösa liv med en utpräglad populärmusikform, dess stil, estetik och i viss bemärkelse även livsstil. För det andra bör det även noteras att denna kombination av kristendom och populärkultur utgör ett transnationellt fenomen. Den finländska kristna metallmusikscenen måste förstås som en del av detta fenomen. Den samtidigt både religiösa och populärkulturella gemenskap som scenen erbjuder sina anhängare blir sålunda förankrad i såväl ett finländskt som ett bredare transnationellt sammanhang.

Det är framför allt inom det specifika rum som utgör den transnationella kristna metallmusikscenen som den kristna metallmusiken görs meningsfull på särskilda sätt. Detta belyser nödvändigheten med att framtida forskning inom detta område i Finland särskilt uppmärksammar hur religiöst meningsskapande allt mer sker $\mathrm{i}$ anslutning till både nationella och bredare transnationella religiösa och kulturella strömningar. I en finländsk kontext återspeglar den kristna metallmusikscenen på så vis ett mer utbrett och växande behov bland unga kristna att uttrycka och utöva sin tro i nära anslutning till alternativa och kulturellt relevanta populärkulturella uttrycksformer. Detta inbegriper då framför allt även dessa populärkulturella formers upplevelsemässiga aspekter samt de kulturella identiteter som de förknippas med. På så vis kan man här också se en strävan efter ett närmare sammankopplande av det religiösa och vardagliga livet. Detta kan också förstås i termer av en rörelse, från det konventionella och traditionella till det nya och innovativa, och från det stela och tråkiga till det engagerande och underhållande. Den kristna metallmusikscenen återspeglar därigenom även ett växande behov bland unga kristna att uttrycka och praktisera religion i egna rum som har en mer direkt anknytning till den bredare kulturella omgivning som de i dagens läge befinner sig $i$.

Här är det slutligen skäl att återknyta till hur allt fler religionsforskare under senare år framhållit populärkulturens allt viktigare roll inom dagens föränderliga religiösa 
Marcus Moberg: Kristen metallmusik. Alternativt religiöst uttryckssätt och kristen identitet

landskap. En mer omfattande förståelse av denna utveckling behöver fler empiriska studier av liknande och relaterade fall. Min fallstudie bidrar dock med en jämförelsepunkt för fortsatt forskning $\mathrm{i}$ hur populärkulturen påverkat det kristna fältet $\mathrm{i}$ Finland.

Moberg, Marcus 2009. Faster for the Master! Exploring Issues of Religious Expression and Alternative Christian Identity within the Finnish Christian Metal Music Scene. Åbo: Åbo Akademi.

Teologie doktor Marcus Moberg forskar inom projektet Post-Secular Culture and a Changing Religious Landscape in Finland (PCCR) i religionsvetenskap vid Åbo Akademi. 